\title{
An Extended VIKOR Method for Ranking Online Graduate Business Programs
}

\author{
Seyhan Nisel, Member, IACSIT
}

\begin{abstract}
The purpose of this study was to introduce an alternative multicriteria decision making methodology for ranking the best online business programs. The Extended VIKOR (Vise Kriterijumska Optimizacija I Kompromisno Resenje) algorithm was used in order to strengthen the ranking methodology created by U.S. News \& World Report and also make the sensitivity analysis of the results. The findings demonstrated that VIKOR algorithm is remarkably successful to determine the best programs which have acceptable advantage or stability in the ranking related to different criteria weights.
\end{abstract}

Index Terms-Distance education, MBA rankings, multicriteria decision making, VIKOR method.

\section{INTRODUCTION}

By the use of many indicators, criteria and the statistical data, the ranking of the best graduate business programs (MBA) worldwide have been created and also published annually by some world famous organizations and magazines. Certainly, official ranking lists are of great interest to candidates who are deciding to choose the right MBA Program. Also each year, schools are striving to provide more quality programs in order to improve their positions assigned by rankings [1]. Consequently, these rankings are becoming popular and important marketing tool every day. However, these rankings have also been a controversial subject and a target of criticism especially in academic society and media. The criticism usually focuses on the reliability of the scoring system, adequacy of selected indicators and criteria, also the accuracy of the criteria weights. Moreover, in recent years, as a consequence of growing demand for the online graduate business programs, the rankings of the online MBA programs also are becoming increasingly popular. Hence the rankings for online MBA programs also tend to attract some criticisms and arguments.

Admittedly, the common aim of the academic studies that assess or discuss the reliability of ranking systems is to improve the overall ranking system in order to produce more accurate ranking results. From this point, the purpose of this study was to introduce an alternative multicriteria decision making methodology for ranking the best online MBA programs. The Extended VIKOR (Vise Kriterijumska Optimizacija I Kompromisno Resenje) algorithm was used in order to strengthen the ranking methodology created by U.S. News \& World Report and also make the sensitivity analysis of the results. The findings demonstrated that VIKOR algorithm is remarkably successful to determine the best

Manuscript received June 11, 2013; revised September 13, 2013.

Seyhan Nisel is with School of Business, Istanbul University, Turkey (e-mail: sipahi@istanbul.edu.tr). programs which have acceptable advantage or stability in the ranking related to different criteria weights.

\section{ONLINE MBA RANKING SYSTEMS}

There are various popular MBA ranking systems that publish an annual list of the best programs worldwide or in US level. The major MBA ranking providers can be summarized as follows [2]:

U.S. News \& World Report [3]: U.S. News and World Report publishes annually the best MBA programs in US level. By surveying deans, MBA program directors and corporate recruiters, it uses a scoring system that takes ratings by business school deans and program directors, ratings by recruiters of the schools, placement statistics, and student selectivity as main indicators.

Financial Times [4]: Financial Times publishes six rankings annually relating to MBA, EMBA, master in finance, master in management programs, non-degree executive education courses, and ranking of top European Business Schools. In the ranking system, career progression of alumni, diversity of faculty, students and board members, the international experience of students, and faculty research and publication are considered as indicators.

Bloomberg Business week [5]: Bloomberg Business week publishes the list of the best MBA programs every two years. The rankings are based on student satisfaction survey, corporate recruiter surveys, as well as research articles and books written by faculty.

Forbes [6]: Forbes publishes the MBA ranking list every two years, and its ranking is based solely on return on investment. It separates schools intofour regions (U.S., Europe, Canada and Asia-Pacific) and the overall performance is calculated by looking at the ranking position within each region.

The Economist [7]: The Economist' MBA school rankings are published every October, and the rankings are broken down by region, including worldwide, Asia, Europe and North America. The rankings are based primarily on survey data from students, alumni and business schools.

Besides ranking systems for the Global MBA, the ranking systems for the online MBA programs in US or worldwide have become available especially in the last three years. The most popular ranking systems for the online MBA programs are "the Best Online Graduate Business Programs" published by US News and World Report, and "the Online MBA Listing" published by Financial Times. Both rankings use overall scoring system considering different indicators, criteria and criteria weights. In this study, the ranking system of the US News and World Report and its ranking list for the year 2013 was used in order to show how VIKOR 
methodology can overcome the weaknesses of the standard scoring systems that the ranking results depend strongly criteria weights given.

\section{VIKOR METHOD}

The VIKOR methodology (Vlse Kriterijumska Optimizacija I Kompromisno Resenje, the Serbian name, means Multi-criteria Optimization and Compromise Solution) [8] was first introduced by Opricovic [9] and Opricovic and Tzeng [10]-[12]. The method can be defined as a multi-criteria optimization of complex systems [11], [12] and it is based on ranking and selecting from a set of alternatives under conflicting criteria. Assuming that each alternative is evaluated according to each criterion function, the compromise ranking could be performed by comparing the measure of closeness to the ideal alternative [12], [13]. The compromise solutions could be the basis for negotiations, involving the preference of decision makers by criteria weights[14].The VIKOR algorithm also determines the weight stability intervals for the obtained compromise solution with the input weights given by the experts [9], [10].

Since its introduction, The VIKOR methodology has been used in many areas such as healthcare applications[15], airline industry [16]-[19], material selection [20]-[24], contractor selection [25], improving tourism policy implementation [26], railway route planning [27], insurance company selection [28], financial performanceevaluation [29], optimization of multi-response processes [30],strategy improving for cruise product sales [31], improving information security risk [32], renevable energy planning [33], [34], creating assessment systems for teaching materials [35], university performance ranking [36], university selection for the future development [37], assessment of university innovation capital indicators [38], vendor or supplier selection [39], [40], brand marketing [41], risk or quality safety evaluation[42], [43], evaluating banking performance [44], personnel training selection [45].

The compromise ranking algorithm of VIKOR has the following steps [11]:

1) Determination of the best $f_{i}^{*}$ and the worst $f_{i}^{-}$values of all criterion functions, $i=1,2, \ldots, n$. If the $i^{\text {th }}$ function represents a benefit then:

$f_{j j}^{*}=\max f_{i j}, \quad f_{i}^{-}=\min f_{i j}$

If the $\mathrm{i}^{\text {th }}$ function represents a cost then:

$f_{j j}^{*}=\min f_{i j}, \quad f_{i}^{-}=\max f_{i j}$

2) Computation of the values $\mathrm{S}_{j}$ and $\mathrm{R}_{j}, j=1,2, \ldots, J$, by the relations

$$
\begin{gathered}
S_{j}=\sum_{i=1}^{n} w_{i}\left(f_{i}^{*}-f_{i j}\right) /\left(f_{i}^{*}-f_{i}^{-}\right) \\
R_{j}=\max \left[w i\left(f_{i}^{*}-f_{i j}\right) /\left(f_{i}^{*}-f_{i}^{-}\right)\right]
\end{gathered}
$$

where $w_{i}$ denotes the weights of criteria.

3) Computation of the values $\mathrm{Q}_{j}, j=1,2, \ldots, J$, by the relation

$$
Q_{j}=v\left(S_{J}-S^{*}\right) /\left(S^{-}-S^{*}\right)+(1-v)\left(R_{j}-R^{*}\right) /\left(R^{-}-R^{*}\right)
$$

where

$$
S^{*}=\min S j, S^{-}=\max S j, R^{*}=\min R j, R^{-}=\max R j
$$

" $v$ " is introduced as the weight of the strategy of "the majority of criteria", (or the maximum group utility), usually $v=0.5$.

4) Rank the alternatives, sorting by the values $S, R$ and $Q$. The results are three ranking lists.

5) Propose as a compromise solution, for given criteria weights, the alternative $\left(a^{\prime}\right)$, which is the best ranked by the measure $Q_{\min }$ if the following two conditions are satisfied:

C1: Acceptable advantage:

$$
Q\left(a^{\prime \prime}\right)-Q\left(a^{\prime}\right) \geq D Q
$$

where $a^{\prime \prime}$ is the alternative with second position in the ranking list by $Q, D Q=1 /(J-1) ; J$ is the number of alternatives.

C2: Acceptable stability in decision making:

The alternative $\mathrm{a}^{\prime}$ must also the best ranked by $\mathrm{S}$ or/and $\mathrm{R}$. This compromise solution is stable within a decision making process, which could be: "voting by majority rule" (when $v>$ 0.5 is needed), or "by consensus" $v \approx 0.5$, or "with veto" ( $v<$ $0.5)$. As indicated before, $v$ represents the weight of the decision making strategy "the majority of criteria" (or "the maximum group utility',).

If one of the conditions is not satisfied, then a set of compromise solutions is proposed, which consists of:

- Alternatives $\mathrm{a}^{\prime}$ and $\mathrm{a}^{\prime \prime}$ if only condition C2 is not satisfied, or

- Alternatives $\mathrm{a}^{\prime}, \mathrm{a}^{\prime \prime}, \ldots, \mathrm{a}^{\mathrm{k}}$ if condition $\mathrm{C} 1$ is not satisfied; and $\mathrm{a}^{\mathrm{k}}$ is determined by the relation

$$
Q\left(a^{k}\right)-Q\left(a^{\prime}\right) \approx D Q
$$

\section{AN EMPIRICAL STUDY}

For generating the online MBA ranking list, U.S. News and World Report firstly collects data and several statistical information from regionally accredited institutions that offer a master's in business MBA program through internet-based distance education courses [3].Then the data are scored, categorized under five major areas that consist of various indicators and criteria. Finally all indicators and also categories are weighted in order to get the overall score of the institutions. The main categories, indicators and the weights used in the ranking methodology are summarized in the Table 1. The detailed information about the criteria and their components can be found on the web page of the U.S. News and World Report [3].

In this study, top hundred online MBA programs according to the ranking list of US News and Report for the year 2013 were ranked again in accordance with the overall scores of universities for five categories (criteria) and their category weights indicated in the Table I. By the use of VIKOR algorithm, $\mathrm{S}_{j}, R_{j}$ and $\mathrm{Q}_{j}$ values were calculated for each ranking alternatives (universities, online MBA programs). In the model, $v$ value was considered 0.5 (the maximum group utility).Table II summarizes the best 20 universities (online 
MBA programs) according to the $Q$ values. Name of the universities were indicated in the appendix.

TABLE I: CRITERIA AND THE WEIGHTS USED IN THE RANKING METHODOLOGY

\begin{tabular}{|c|c|c|}
\hline $\begin{array}{l}\text { Category } \\
\text { (Criteria) }\end{array}$ & $\begin{array}{l}\text { Weight } \\
(\%)\end{array}$ & Ranking Indicators \\
\hline $\begin{array}{l}\text { Student } \\
\text { engagement }\end{array}$ & 28 & $\begin{array}{l}\text { Graduation rate, best practices, } \\
\text { program level accreditation, class } \\
\text { size, one year retention rates, time to } \\
\text { degree deadline. }\end{array}$ \\
\hline $\begin{array}{l}\text { Admissions } \\
\text { selectivity }\end{array}$ & 25 & $\begin{array}{l}\text { GMAT Scores, GPA scores, } \\
\text { acceptance rate, employee } \\
\text { sponsorship, experience, letters of } \\
\text { recommendation (general), letters of } \\
\text { recommendations } \\
\text { (professionals). }\end{array}$ \\
\hline Peer reputation & 25 & $\begin{array}{l}\text { A school's weighted mean of scores } \\
\text { on a } 1-5 \text { scale from marginal to } \\
\text { outstanding as submitted by peer } \\
\text { institutions, multiplied by } 20 \text {. }\end{array}$ \\
\hline $\begin{array}{l}\text { Faculty } \\
\text { credentials and } \\
\text { training }\end{array}$ & 11 & $\begin{array}{l}\text { Ph.D. faculty, tenured faculty, } \\
\text { financed training, hours of faculty } \\
\text { training, continuing faculty } \\
\text { education, peer review. }\end{array}$ \\
\hline $\begin{array}{l}\text { Student services } \\
\text { and technology }\end{array}$ & 11 & $\begin{array}{l}\text { Student indebtedness, Technologies } \\
\text { accessible to students, service } \\
\text { available to students. }\end{array}$ \\
\hline
\end{tabular}

TABLE II: VIKOR RANKING RESULTS

\begin{tabular}{|l|c|c|c|c|c|c|c|}
\hline \hline & $\mathbf{S}_{\mathbf{J}}$ & $\mathbf{R}_{\mathbf{J}}$ & $\mathbf{Q}_{\mathbf{J}}$ & $\begin{array}{c}\text { Rank } \\
\left(\mathbf{Q}_{\mathbf{J}}\right.\end{array}$ & $\begin{array}{c}\text { Rank } \\
\text { (USw) }\end{array}$ & $\mathbf{C}_{\mathbf{1}}$ & $\mathbf{C}_{\mathbf{2}}$ \\
\hline U1 & 0.175 & 0.057 & 0.000 & 1 & 2 & YES & YES \\
U2 & 0.181 & 0.067 & 0.028 & 2 & 3 & YES & YES \\
U3 & 0.186 & 0.083 & 0.132 & 3 & 1 & NO & NO \\
U4 & 0.221 & 0.086 & 0.136 & 4 & 4 & YES & NO \\
U5 & 0.251 & 0.097 & 0.167 & 5 & 7 & YES & NO \\
U6 & 0.284 & 0.107 & 0.182 & 6 & 8 & YES & NO \\
U7 & 0.291 & 0.109 & 0.246 & 7 & 5 & YES & NO \\
U8 & 0.292 & 0.109 & 0.266 & 8 & 16 & NO & NO \\
U9 & 0.296 & 0.109 & 0.272 & 9 & 14 & NO & NO \\
U10 & 0.306 & 0.111 & 0.273 & 10 & 19 & YES & NO \\
U11 & 0.307 & 0.111 & 0.287 & 11 & 23 & NO & NO \\
U12 & 0.307 & 0.112 & 0.287 & 12 & 17 & NO & NO \\
U13 & 0.316 & 0.117 & 0.294 & 13 & 15 & NO & NO \\
U14 & 0.321 & 0.118 & 0.295 & 14 & 22 & NO & NO \\
U15 & 0.326 & 0.119 & 0.298 & 15 & 25 & NO & NO \\
U16 & 0.330 & 0.126 & 0.308 & 16 & 6 & NO & NO \\
U17 & 0.332 & 0.127 & 0.313 & 17 & 21 & YES & NO \\
U18 & 0.339 & 0.129 & 0.335 & 18 & 20 & YES & NO \\
U19 & 0.342 & 0.130 & 0.359 & 19 & 10 & NO & NO \\
U20 & 0.343 & 0.130 & 0.367 & 20 & 30 & NO & NO \\
\hline \hline
\end{tabular}

From the Table II, it can be seen that Arizona State University is the best ranked alternative according to the VIKOR ranking. Indiana University (Bloomington) is the second ranked alternative. Moreover, Arizona State University and Indiana University have good advantage and also good stability as they both satisfy "condition $C_{1}$ " and "condition $C_{2}$ ". Arizona State University is a real compromise. Inspecting the Table II, it can be noticed that the ranking positions of the top 20 universities in the VIKOR ranking are quite different from those US News and Report ranking. As a fourth ranked university, only "University of Florida" keeps the same position in both rankings. The best ranked university in the US and Report ranking (Washington State) is in the third place in the VIKOR ranking. Moreover, Washington State has no any good advantage or stability, as it cannot satisfy $\mathrm{C}_{1}$ and $\mathrm{C}_{2}$. It means that in can lose its position easily for different criteria weights. Arizona State University, Indiana University, University of Florida, Auburn University, University of Connecticut, California State University Fullerton, Pennsylvania State University, University of Michigan, and University of North Texas are the alternatives with good advantage by satisfying $C_{1}$. The weight stability intervals in the Table III present the stability of the best ranked university (Arizona State) for a range of weight values for each five category. For "student engagement", the top position of Arizona University will remain the same for weight values of 0 through $21 \%$. When the weight values for "admissions selectivity" stand between 0 through 19\%, Arizona will be again the top ranked university. "Faculty credentials and training" has the widest range (0 through 56\%) for keeping the top position of Arizona University. However, it can lose the first place for "student services and technology" category for the range values less than $17 \%$ or greater than $32 \%$.

TABLE III:WEIGHT STABILITY INTERVALS FOR ARIZONA UN
\begin{tabular}{|l|c|c|c|}
\hline & Initial & $\mathbf{W}^{\mathbf{L}}$ & $\mathbf{W}^{\mathbf{U}}$ \\
\hline Student engagement & 0.11 & 0.00 & 0.21 \\
\hline Admissions selectivity & 0.11 & 0.00 & 0.19 \\
\hline Peer reputation & 0.28 & 0.18 & 0.54 \\
\hline $\begin{array}{l}\text { Faculty credentials and } \\
\text { training }\end{array}$ & 0.25 & 0.00 & 0.56 \\
\hline $\begin{array}{l}\text { Student services and } \\
\text { technology }\end{array}$ & 0.25 & 0.17 & 0.32 \\
\hline
\end{tabular}

\section{CONCLUSION}

Several official ranking systems produce and publish annually the league tables and the best school ranking lists in terms of the undergraduate or graduate programs. Increasing criticisms about the methodologies used in the ranking systems are in effort to develop better evaluation systematics. Whatever the methodology used a heavy dependence between the criteria weights and the ranking results have been observed in such systems. Thus it is essential to synthesize the results by the use of sophisticated quantitative techniques and to make sensitivity analysis related to criteria weights. In this study, the ranking list for the best online MBA programs by US News and World report was analyzed by the use of VIKOR method. The VIKOR algorithm is based on the evaluation of alternatives by the closeness to the ideal solution, and it is particularly capable on solving multicriteria complex systems. The results demonstrated that the position 
of universities (online MBA programs) can fluctuate in the list while taking all ranked candidates into consideration. Moreover, under the given criteria weights, the acceptable advantage and the acceptable stability of universities were calculated, reflecting one of the strengths of the VIKOR algorithm. Also the weight stability intervals showed that the position of the highest ranked university is sensitive to criteria weights. Consequently the sensitivity analysis of the proposed methodology can be successfully applied to monitor the overall performance of the schools and to determine the strengths and weaknesses ofthe online MBA programs.

\section{APPENDIX} NAME OF UNIVERSITIES (ONLINE MBA PROGRAMS) IN THE VIKOR
RANKING

\begin{tabular}{|ll|}
\hline \hline & Name of Universities in the VIKOR Ranking \\
\hline U1 & Arizona State University (Carey) \\
U2 & Indiana University-Bloomington (Kelley) \\
U3 & Washington State University \\
U4 & University of Florida (Hough) \\
U5 & Auburn University \\
U6 & University of Connecticut \\
U7 & California State University-Fullerton \\
U9 & University of Illinois-Springfield \\
U10 & Pennsylvania State University-World Campus \\
U11 & University of San Diego \\
U12 & University of Nebraska-Lincoln \\
U13 & Georgia College \& State University (Bunting) \\
U14 & University of Massachusetts-Amherst (Isenberg) \\
U15 & Thunderbird School of Global Management \\
U16 & Central Michigan University \\
U17 & University of Michigan-Dearborn \\
U18 & University of North Texas \\
U19 & University of Tennessee-Martin \\
U20 & Syracuse University (Whitman) \\
\hline
\end{tabular}

\section{REFERENCES}

[1] M. Koksalan et al., "A flexible approach to ranking with an application to MBA programs," European Journal of Operational Research, vol. 201, no. 2, pp. 470-476, 2010.

[2] How to MBA. (24 May 2013). [Online]. Available: http://howtomba.com/how-to-find-your-mba/mba-rankings.

[3] US News and Reports Graduate School Rankings. (24 May 2013). [Online]. Available: http://grad-schools.usnews.rankingsandreviews.com/best-graduate-sc hools

[4] Financial Times Global MBA Rankings. (24 May 2013). [Online]. Available: http://rankings.ft.com/businessschoolrankings/global-mbaranking-2013.

[5] Bloomberg Businessweek Graduate Business Schools Rankings. (24 May 2013). [Online]. Available: http://www.businessweek.com/ bschools/rankings.

[6] Forbes MBA rankings. (24 May 2013). [Online]. Available: http://www.forbes.com/sites/mattsymonds/2012/11/29/the-best-busine ss-schools-of-2012-the-ranking-of-mba-rankings.

[7] The Economist Full-time MBA rankings. (24 May 2013). [Online]. Available: http://www.economist.com/whichmba/full-time-mbaranking.
[8] M. T. Chu et al., "Comparison among three analytical methods for knowledge communities group-decision analysis," Expert systems with applications, vol. 33, no. 4, pp. 1011-1024, 2007.

[9] S. Opricovic, "Multicriteria optimization of civil engineering systems," Faculty of Civil Engineering, Belgrade, vol. 2, no. 1, pp. 5-21, 1998.

[10] G. H. Tzeng et al., "Multicriteria selection for a restaurant location in Taipei," International Journal of Hospitality Management, vol. 21, no. 2, pp. 171-187, 2002.

[11] S. Opricovic and G. H. Tzeng, "Extended VIKOR method in comparison with outranking methods," European Journal of Operational Research, vol. 178, pp. 514-529, 2007.

[12] S. Opricovic and G. H. Tzeng, "Compromise Solution by MCDM Methods: A comparative analysis of VIKOR and TOPSIS," European Journal of Operational Research, vol. 156, pp. 445-455, 2004.

[13] S. Opricovic and G. S. Tzeng. "Multicriteria planning of post-earthquake sustainable reconstruction," Computer-Aided Civil and Infrastructure Engineering, vol. 17, no. 3, pp. 211-220, 2002.

[14] S. Opricovic, "Compromise in cooperative game and the VIKOR method," The Yugoslav Journal of Operations Research, ISSN: 0354-0243 EISSN: 2334-6043, vol. 19, no. 2, 2009.

[15] Q. L. Zeng, D. D. Li, and Y. B. Yang. "VIKOR Method with Enhanced Accuracy for Multiple Criteria Decision Making in Healthcare Management," Journal of Medical Systems, vol. 37, no. 2, pp. 1-9, 2013.

[16] H. Y. Wu, J. K. Chen, and I. S. Chen, "Performance evaluation of aircraft maintenance staff using a fuzzy MCDM approach," International Journal of Innovative Computing Information and Control, vol. 8, no. 6, pp. 3919-3937, June 2012.

[17] J. H Liou et al., "A modified VIKOR multiple-criteria decision method for improving domestic airlines service quality," Journal of Air Transport Management, vol. 17, no. 2, pp. 57-61, 2011

[18] M. S. Kuo and G. S. Liang. "Combining VIKOR with GRA techniques to evaluate service quality of airports under fuzzy environment," Expert Systems with Applications, vol. 38, no. 3, pp. 1304-1312, 2011.

[19] W. H. Tsai, W. C. Chou, and J. D. Leu, "An effectiveness evaluation model for the web-based marketing of the airline industry," Expert Systems with Applications, vol. 38, pp. 15499-15516, 2011.

[20] A. Jahan et al., "A comprehensive VIKOR method for material selection," Materials and Design, vol. 32, no. 3, pp. 1215-1221, 2011.

[21] A. C. R. Vaish, "A comparative study on material selection for micro-lectromechanical systems," Materials and Design, vol. 41, pp. 177-181, 2012.

[22] B. Marjan and A. Jahan. "Material selection for femoral component of total knee replacement using comprehensive VIKOR," Materials and Design, vol. 32, no. 8, pp. 4471-4477, 2011.

[23] C. H. Liu et al., "Induced aggregation operators in the VIKOR method and its application in material selection," Applied Mathematical Modelling, 2013.

[24] V. M. Athawale and S. Chakraborty, "Material selection using multi-criteria decision-making methods: a comparative study," in Proc. the Institution of Mechanical Engineers, Part L: Journal of Materials Design and Applications, pp. 226-266, 2012.

[25] J. R. S. Cristobal, "Contractor selection using multicriteria decision-making methods," Journal of Construction Engineering and Management, vol. 138, no. 6, pp. 751-758, June 2012

[26] C. H. Liu, G. H. Tzeng, and M. H. Lee, "Improving tourism policy implementation - The use of hybrid MCDM models," Tourism Management, vol. 33, pp. 413 - 426, 2012.

[27] M. Kosijer et al., "Multicriteria decision-making in railway route planning and design," Gradevinar, vol. 64, no. 3, pp. 195-205, March 2012.

[28] G. N. Yucenur and N. C. Demirel, "Group decision making process for insurance company selection problem with extended VIKOR method under fuzzy environment," Expert Systems with Applications, vol. 39, pp. 3702-3707, 2012.

[29] N. Yalcin, A. Bayrakdaroglu, and C. Kahraman, "Application of fuzzy multi-criteria decision making methods for financial performance evaluation of Turkish manufacturing industries," Expert Systems with Applications, vol. 39, pp. 350-364, 2012.

[30] L. I. Tong, C. C. Chen, and C. H. Wang, "Optimization of multi-response processes using the VIKOR method," International Journal of Advanced Manufacturing Technology, vol. 31, pp. 1049-1057, 2007

[31] C. H. Liu, G. H. Tzeng, and M. H. Lee, "Strategies for improving cruise product sales in the travel agency using hybrid MCDM models," The Service Industries Journal ahead-of-print, pp. 1-22, 2011.

[32] O. Yang et al., "A VIKOR-based multiple criteria decision method for improving information security risk," International Journal of Information Technology \& Decision Making, vol. 8, pp. 267-287, 2009. 
[33] J. R. San Cristobal, "Multi-criteria decision-making in the selection of a renewable energy project in Spain: the VIKOR method," Renewable Energy, vol. 36, no. 2, pp. 498-502, 2011.

[34] T. Kaya and C. Kahraman, "Multicriteria renewable energy planning using an integrated fuzzy VIKOR \& AHP methodology: The case of Istanbul," Energy, vol. 35, no. 6, pp. 2517-2527, 2010.

[35] C. H. Chen and G. H. Tzeng, "Creating the aspired intelligent assessment systems for teaching materials," Expert Systems with Applications, vol. 38, no. 10, pp. 12168-12179, 2011.

[36] H. Y. Wu et al., "Ranking universities based on performance evaluation by a hybrid MCDM model," Measurement, vol. 45, pp. 856-880, 2012.

[37] J. K. Chen and I. Chen. "VIKOR Method for Selecting Universities for Future Development Based on Innovation," Online Submission, 2008.

[38] H. Y. Wu, J. K. Chen, and I. S. Chen, "Innovation capital indicator assessment of Taiwanese Universities: A hybrid fuzzy model application," Expert Systems with Applications, vol. 37, pp. 1635-1642, 2010.

[39] C. H. Hsu, F. K. Wang, and G. H. Tzeng, "The best vendor selection for conducting the recycled material based on a hybrid MCDM model combining DANP with VIKOR," Resources, Conservation and Recycling, 2012.

[40] S. A. Panjeh and A. Sasani, "Applying Logarithmic Fuzzy Preference Programming and VIKOR Methods for Supplier Selection: A Case Study," Journal of American Science, vol. 9, no. 1, 2013.

[41] Y. L. Wang and G. H. Tzeng, "Brand marketing for creating brand value based on a MCDM model combining DEMATEL with ANP and VIKOR methods," Expert Systems with Applications, vol. 39, no. 5, pp. 5600-5615, 2012.

[42] H. C. Liu et al., "Risk evaluation in failure mode and effects analysis with extended VIKOR method under fuzzy environment," Expert Systems with Applications, vol. 39, pp. 12926-12934, 2012.
[43] S. H. Bin et al., "A synthetic evaluation model for consumer products quality safety based on the VIKOR method," Information - An International Interdisciplinary Journal, vol. 15, no. 10, pp. 4037-4047, October 2012.

[44] H. Y. Wu, G. H. Tzeng, and Y. H. Chen, "A fuzzy MCDM approach for evaluating banking performance based on Balanced Scorecard," Expert Systems with Applications, vol. 36, pp. 10135-10147, 2009.

[45] M. F. El-Santawy, "A VIKOR Method for Solving Personnel Training Selection Problem," International Journal of Computing Science, Research Pub, vol. 1, no. 2, pp. 9-12, 2012.

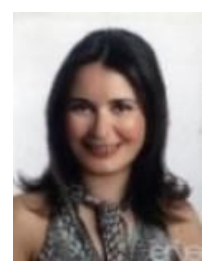

Seyhan Nisel is an associate professor of Quantitative Methods at School of Business, Istanbul University. She earned her BS in Business Administration from the Istanbul University and her MA and $\mathrm{PhD}$ in Quantitative Methods from the Social Science Institute of the Istanbul University. Her PhD thesis was on "Ranking Cities of Turkey by Livability Using Analytic Hierarchy Process". In 2007, she was visiting research scholar a Operations and Decision Technologies Department at Kelley School of Business, Indiana University. Her primary fields of research are spreadsheet modeling, performance measurement and ranking, multicriteria decision making in business, simulation optimization, and management science applications in sport. She has several national and international articles and conference papers published in reputed academic journals and proceeding books. She is associate editor of the "Journal of the School of Business Administration", Istanbul University. She is also the institutional contact point at Istanbul University for EU framework research programs. She works for Quantitative Methods Department, School of Business since 1997. 